\title{
Phosphorus Fluxes in a Temperate Forested Watershed: Canopy Leaching, Runoff Sources, and In-Stream Transformation
}

OPEN ACCESS

Edited by:

Edith Bai,

Institute of Applied Ecology

(CAS), China

Reviewed by:

John T. Van Stan,

Georgia Southern University,

United States

Ingeborg Callesen,

University of Copenhagen, Denmark

*Correspondence:

Jakob Sohrt

jakob.sohrt@posteo.de

${ }^{\dagger}$ Present address:

David Uhlig,

Institute of Bio- and Geosciences

(IBG-3) Agrosphere,

Forschungszentrum Jülich,

Jülich, Germany

Specialty section:

This article was submitted to

Forest Soils,

a section of the journal

Frontiers in Forests and Global

Change

Received: 25 September 2019 Accepted: 02 December 2019 Published: 17 December 2019

Citation:

Sohrt J, Uhlig D, Kaiser K, von Blanckenburg F, Siemens J,

Seeger S, Frick DA, Krüger J, Lang F and Weiler M (2019) Phosphorus

Fluxes in a Temperate Forested Watershed: Canopy Leaching, Runoff

Sources, and In-Stream

Transformation.

Front. For. Glob. Change 2:85.

doi: 10.3389/ffgc.2019.00085

\begin{abstract}
Jakob Sohrt ${ }^{1 *}$, David Uhlig ${ }^{2 \dagger}$, Klaus Kaiser ${ }^{3}$, Friedhelm von Blanckenburg ${ }^{2}$, Jan Siemens ${ }^{4}$, Stefan Seeger ${ }^{1}$, Daniel A. Frick ${ }^{2}$, Jaane Krüger ${ }^{5}$, Friederike Lang $^{5}$ and Markus Weiler ${ }^{1}$

${ }^{1}$ Chair of Hydrology, University of Freiburg, Freiburg im Breisgau, Germany, ${ }^{2}$ GFZ German Research Centre for Geosciences, Section Earth Surface Geochemistry, Potsdam, Germany, ${ }^{3}$ Soil Science and Soil Protection, Martin Luther University Halle-Wittenberg, Halle (Saale), Germany, ${ }^{4}$ iFZ Research Centre for Biosystems, Land Use and Nutrition, Institute of Soil Science and Soil Conservation, Justus Liebig University Giessen, Giessen, Germany, ${ }^{5}$ Chair of Soil Ecology, University of Freiburg, Freiburg im Breisgau, Germany
\end{abstract}

Declining foliar phosphorus $(\mathrm{P})$ levels call increasing attention to the cycling of this element in temperate forests. We explored the fluxes of $\mathrm{P}$ in a temperate mixed deciduous forest ecosystem in six distinct hydrological compartments: Bulk precipitation and throughfall, soil water draining laterally from three different soil depths $(0-15,15-150,150-320 \mathrm{~cm}$ below soil surface), groundwater, creek and spring discharge, which were sampled at daily to bi-weekly resolution from March 2015 to February 2016. Atmospheric P fluxes into the ecosystem were equally partitioned between wet and dry deposition. Approximately $10 \%$ of the foliar $\mathrm{P}$ stock was lost annually by foliar leaching during late summer. The concentrations of dissolved $P$ in soil water from the forest floor and upper mineral topsoil followed a pronounced seasonal cycle with higher concentrations during the vegetation period. The concentrations of $\mathrm{P}$ dissolved in soil water decreased with increasing soil depth. Using an end member mixing analysis (EMMA) we found that $P$ sources feeding the spring water were both soil water from greater depths or groundwater with season specific contributions. Atmospheric P fluxes into the ecosystem determined in this study and P-release from weathering reported for the research site were large enough to compensate $P$ losses with runoff. This suggests that declining foliar $\mathrm{P}$ levels of forests are unlikely the result of a dwindling total $\mathrm{P}$ supply, but rather caused by tree nutrition imbalances or alternative stressors.

Keywords: hydrological P cycle, canopy $\mathrm{P}$ balance, atmospheric $\mathrm{P}$ deposition, groundwater, discharge, soil water, EMMA, periphyton

\section{INTRODUCTION}

The primary productivity of forest ecosystems is often limited or co-limited by $\mathrm{P}$ availability (Elser et al., 2000, 2007; Vitousek et al., 2010; Achat et al., 2016). Over the past decades, foliar P concentrations were observed to decline in temperate forests but it is not yet clear whether this decline indicates P limitation (Duquesnay et al., 2000; Jonard et al., 2014; Talkner et al., 2015). Thus, better constraints on $\mathrm{P}$ cycling in forest ecosystems are required to identify the mechanisms of the respective forest ecosystem functioning (Lang et al., 2016, 2017). 
The $\mathrm{P}$ cycle in temperate forests depends mainly on the general boundary conditions of the past and present, which are the drivers of the local ecosystem development (Walker and Syers, 1976). Important boundary conditions include lithology as the original source of most ecosystem $\mathrm{P}$ as well as climate and topography as controls of the water cycle, erosion-sedimentation, weathering processes and soil development, through which the bio-availability of $\mathrm{P}$ is determined (Laliberté et al., 2013). Fluxes of $\mathrm{P}$ across the ecosystem boundaries occur through runoff and atmospheric transport, which may result in either net gains or losses (Newman, 1995; Mahowald et al., 2008; Buendia et al., 2010; Tipping et al., 2014). The P deposition in bulk precipitation and throughfall mostly exceeds the $\mathrm{P}$ export by discharge (Cole and Rapp, 1981; Sohrt et al., 2017), but this does not necessarily imply that the overall $\mathrm{P}$ balance is positive. The $\mathrm{P}$ exports from an ecosystem via atmospheric pathways, e.g., pollen dispersion, are hard to quantify, which likely causes overestimation of net atmospheric deposition (Doskey and Ugoagwu, 1989; Newman, 1995; Tipping et al., 2014). Average estimates for above canopy atmospheric deposition mostly range from 10 to $100 \mathrm{mg} \mathrm{P} \mathrm{m}^{-2}$ $\mathrm{a}^{-1}$; discharge losses are typically in the range of $1-10 \mathrm{mg} \mathrm{P} \mathrm{m}^{-2}$ $\mathrm{a}^{-1}$ (Cole and Rapp, 1981; Sohrt et al., 2017).

In comparison to abiotic fluxes across ecosystem boundaries, internal $\mathrm{P}$ fluxes within ecosystems associated with biotic processes are much larger (Rodin et al., 1967; Cole and Rapp, 1981; Turner, 1981; Compton and Cole, 1998; Ilg et al., 2009; Bol et al., 2016). Litterfall represents a flux of 100 to $500 \mathrm{mg} P$ $\mathrm{m}^{-2} \mathrm{a}^{-1}$, about $60-80 \%$ of which is contained in foliar litter (Sohrt et al., 2017). Plant nutrient uptake from soil necessarily exceeds nutrient fluxes from litter fall, since $\mathrm{P}$ in growing tissue and losses via dead roots or herbivory have to be additionally compensated for. Another biotic flux within temperate forests highly relevant to the internal $\mathrm{P}$ cycling is related to bacteria and fungi. The microbial biomass comprises on average 20$40 \%$ of the total biomass $\mathrm{P}$, which cycles at the scale of weeks to months (Raubuch and Joergensen, 2002; Spohn and Widdig, 2017), whereas $P$ contained in woody biomass may persist for years to decades. While its measurement is still challenging, microbial uptake and subsequent leaching from dead microbial biomass must be considered as major internal fluxes in the P cycle of temperate forests (Horwath, 2017).

Quantifying P fluxes within the hydrological cycle has been identified as a priority to close gaps in a full quantification of $\mathrm{P}$ cycling in forest ecosystems (Bol et al., 2016). Fundamental observations made so far include the following: When passing through the canopy, rainwater is on average enriched 2-fold in $\mathrm{P}$ and the $\mathrm{P}$ content is doubled again during percolation through the forest floor (Sohrt et al., 2017). Beneath the forest floor, dissolved $\mathrm{P}$ concentrations and fluxes decline with increasing depth since $\mathrm{P}$ is effectively retained during percolation through the upper mineral soil (Cole and Rapp, 1981; Persson and Broberg, 1985; Jansson et al., 1986; Killingbeck, 1986; Stevens et al., 1989; Brown and Iles, 1991; Qualls and Haines, 1991; Saa et al., 1993; Sparling et al., 1994; Compton and Cole, 1998; Kaiser et al., 2001a,b; Sohrt et al., 2017). In contrast to throughfall and water in the forest floor, soil water, and groundwater in the weathered and fractured bedrock features the lowest dissolved $\mathrm{P}$ contents of all hydrological compartments
(Dillon and Kirchner, 1975; Timmons et al., 1977; Reckhow et al., 1980; Mulholland et al., 1990; Qualls et al., 2002; Schwärzel et al., 2012; Verheyen et al., 2015). Thus, due to the large variation of $\mathrm{P}$ concentrations, discharge generation from either groundwater or soil water sources may control the P concentrations of stream water. Supporting evidence for this assumption stems from time series of dissolved $\mathrm{P}$ contents in groundwater and discharge in forested headwaters showing that $\mathrm{P}$ concentrations in discharge are consistently higher and more variable than in groundwater (Verheyen et al., 2015).

However, the dissolved $\mathrm{P}$ concentrations in forest headwater catchments are not only controlled by the contribution from different runoff sources, but also by abiotic adsorption/desorption processes or biotic in-stream processes. For example, biota in the stream channel can seasonally act both as a source and sink of $\mathrm{P}$, effectively shaping the $\mathrm{P}$ concentration in lower order forest streams (Gregory, 1978; Munn and Meyer, 1990; Hill et al., 2001; Mulholland, 2004; Winkelmann et al., 2014). A short period of higher $P$ concentrations in streamflow has been observed when freshly fallen litter enters the stream, which is attributed to P leached from litter (Triska et al., 1975). A simultaneous pulse of $P$ leaching from the forest floor directly after litter fall has also been reported (Gosz et al., 1973; Baldwin, 1999). After initial leaching of rapidly mobilizable $\mathrm{P}$, net retention of $\mathrm{P}$ in microbial biomass in the stream takes place, which may extend into the early summer of the following year, causing a depression of $\mathrm{P}$ concentrations (Sedell et al., 1975; Mulholland, 1992, 2004; Mulholland and Hill, 1997). By applying a radioactive phosphate tracer $\left({ }^{32} \mathrm{PO}_{4}{ }^{3-}\right)$, Elwood et al. (1983), and Mulholland et al. (1985) showed that the average uptake length of phosphate between desorption and resorption in low-order forest streams is in the range of $5-160 \mathrm{~m}$, and that the uptake length increases from the time of litter fall to summer. Similar mean uptake lengths have been recorded for ammonium, while mean uptake lengths for nitrate appear to be substantially larger (Peterson et al., 2001; Webster et al., 2001; Bernhardt and Likens, 2002). Apart from the in-stream heterotrophic decomposer community, periphyton can also shape $\mathrm{P}$ concentrations. Since the primary productivity of periphyton is limited by sunlight, its $\mathrm{P}$ consumption and hence decreasing $\mathrm{P}$ concentrations are restricted to the time before spring budbreak (Friberg et al., 1997; Mulholland and Hill, 1997; Hill et al., 2001; Winkelmann et al., 2014). As a consequence, $\mathrm{P}$ concentrations in low order forest streams appear to be either chemostatic, with little or no changes in response to discharge and seasonality (Meyer and Likens, 1979; Benning et al., 2012), or biotically controlled, with minima in spring and fall (Mulholland, 1992, 2004; Rosemond, 1994; Mulholland and Hill, 1997; Roberts et al., 2007; Zelazny and Siwek, 2012; Bernal et al., 2015; Verheyen et al., 2015).

In summary, a number of studies addressed single fluxes of $\mathrm{P}$ in great details, but studies exploring relationships between multiple input and output fluxes are scarce, especially for forested catchments. We therefore aimed to quantify hydrological output fluxes of $\mathrm{P}$ and relate them to $\mathrm{P}$ gains from atmospheric deposition. By sampling water at daily to bi-weekly resolution from six distinct hydrological compartments-bulk precipitation, throughfall, subsurface flow 
in three depth increments, groundwater, spring discharge, and creek discharge-we determined mobilization and transport of $\mathrm{P}$ as well as their temporal variation. We focus on the $\mathrm{P}$ canopy balance, the relative contribution of $\mathrm{P}$ from soil water and groundwater to discharge in a spring and a first order headwater, and the respective $\mathrm{P}$ fluxes. In this way, we intend to spotlight $\mathrm{P}$ fluxes in different hydrological compartments and their relation to each other as well as to investigate, whether the observed changes in forests $\mathrm{P}$ cycles are explained by unbalanced $P$ budgets.

\section{Study Site}

The study was conducted at the "Conventwald" research site located in the Black Forest, Germany $\left(48^{\circ} 02^{\prime} 0\right.$ N, $07^{\circ} 96^{\prime} 0$ E). Our study area consists of two neighboring watersheds: the "creek" catchment with long-term discharge monitoring of a headwater creek, and the "spring" catchment. The average elevation of the two headwater catchments was $840 \mathrm{~m}$ a.s.l., mean annual temperature was $6.6^{\circ} \mathrm{C}$, and mean annual precipitation was $1,749 \mathrm{~mm} \mathrm{a}^{-1}$. Being part of the European "Level II" (ICP Forest) environmental monitoring network, the Conventwald was equipped some decades ago with instruments to monitor bulk precipitation and throughfall, soil moisture, soil water, and stream discharge in the creek catchment. New instrumentation in the spring catchment included $10 \mathrm{~m}$ long collectors for lateral subsurface flow, collecting water at three depth intervals (0-15, 15-150, 150-320 cm below soil surface), a groundwater well with a depth of $15 \mathrm{~m}$ drilled through the saprolite into the fractured bedrock and a weir at the spring catchment. The subsurface flow collectors including their installation are described in detail in Bachmair and Weiler (2012).Time series of soil moisture, bulk precipitation, throughfall, and plant-phenological data were kindly provided by the Forest Research Institute of BadenWuerttemberg (FVA). With a surface area of $0.086 \mathrm{~km}^{2}$, the creek catchment was slightly larger than the spring catchment with an area of $0.077 \mathrm{~km}^{2}$. Exposition was south-east for the creek catchment and south-south-west for the spring catchment. The average slope was about $20^{\circ}$ at both catchments. In the creek catchment, an open channel bed was present, reaching up to $40 \%$ of the way from the catchment outlet to the ridge, the upper part of which was ephemeral. By contrast, the spring catchment had no permanent surface water flow at all and was instead drained by a spring at the catchment outlet. It was evident, however, that this spring did not represent the complete discharge from the catchment area, as additional below ground discharge was visible some meters down-slope in the form of water leaking from a road cut. The existence of below ground discharge was also evident since the specific discharge from the spring catchment is only $\sim 60 \%$ of that from the creek catchment, which, given their topographic and hydrological similarity, was not plausible. Therefore, below ground discharge from the spring catchment was estimated in such a way that its average specific discharge (discharge rates normalized to catchment area) matches that of the creek catchment.

At the creek catchment the vegetation consisted of European beech [Fagus sylvatica (L.), 69\%] and White fir (Abies alba (Mill.), 31\%) (Lang et al., 2017). At the spring catchment, the tree species distribution was slightly different with 45\% Norway spruce [Picea abies (L.)], 40\% European beech [Fagus sylvatica (L.)], 15\% Douglas fir [Pseudotsuga menziesii (Mirb.)] and small amounts of White fir [Abies alba (Mill.)] [personal communications, Forest Research Institute BadenWuerttemberg (FVA), 2018]. The soil type in both catchments was a Hyperdystric Skeletic Folic Cambisol with a loamy or sandy loamy texture and a mor-type moder forest floor atop (Lang et al., 2017). The soils have formed on periglacial slope deposits and the uppermost meter of soil had a rock fragment content of about $70 \%$ (Lang et al., 2017). The dominant fraction of $\mathrm{P}$ in the forest floor is organically bound. In the mineral soil, the portion of organically-bound $\mathrm{P}$ decreased with depth and, in turn, that of $\mathrm{P}$ bound to secondary $\mathrm{Fe}$ - and $\mathrm{Al}$ oxides increased (Lang et al., 2017; Uhlig and von Blanckenburg, 2019b).Weathered bedrock was found at a depth of $7 \mathrm{~m}$ and parent bedrock (paragneiss) at $15 \mathrm{~m}$ (Uhlig and von Blanckenburg, 2019a). The dominant P-containing mineral in unweathered paragneiss bedrock was apatite, as inferred from scanning electron microscopic imaging in combination with elemental analyses with energy-dispersive $\mathrm{X}$-ray spectroscopy (unpublished data).

As the Conventwald study site is part of the ICP Forest sites, extensive scientific background information is available on the topics of hydrology (Uhlenbrook et al., 1998; Hangen et al., 2001), soils (Kohler et al., 2000), and plant water use (Rennenberg and Schraml, 2000; Magh et al., 2017). The Conventwald site is also part of the DFG-funded priority project (SPP 1685): Ecosystem Nutrition-Forest Strategies for limited Phosphorus Resources, providing background information on soil P speciation (Prietzel et al., 2016; Lang et al., 2017; Stahr et al., 2017; Werner et al., 2017), colloidal P transport in soil water and streamflow (Missong et al., 2016, 2017; Gottselig et al., 2017), and on P cycling in plant and microbial biomass (Heuck et al., 2015; Bergkemper et al., 2016; Zavišić et al., 2016).

\section{METHODS}

\section{Sampling}

Sample collection was carried out from 01.03.2015 to 25.02.2016. Daily samples of groundwater, creek, and spring discharge were taken at midnight with automatic samplers. Bulk precipitation, throughfall, and lateral subsurface water were sampled in bulk containers and collected twice a week. To avoid contamination, the precipitation samplers were covered with a netting of $0.5 \mathrm{~mm}$ mesh size. Stemflow was only assessed with respect to water flow (no P concentrations). For the purpose of this study, water flow associated with stemflow was included into the throughfall fraction and assumed to feature comparable $\mathrm{P}$ concentrations. For some tree species stemflow has been found to be highly enriched in $\mathrm{P}$ compared to throughfall (Schroth et al., 2001; Neal et al., 2003). However, the few available studies on Fagus species' stemflow $\mathrm{P}$ concentrations found them to be roughly equivalent to throughfall (Voigt, 1960; Nihlgård, 1970). The reson for this may be, that Fagus sylvatica produces relatively large quantities of stemflow, causing a dilution effect. All precipitation samples with visible particular contamination were excluded from further analysis. All samples were stored 
in polypropylene bottles that were cleaned prior to sampling with P-free detergent and deionized water (Milli-Q, $18 \mathrm{M} \Omega \cdot \mathrm{cm}$ ). After collection, all samples were filtered through membranes of $0.8 \mu \mathrm{m}$ pore size (Supor-800, Pall Laboratories) and aliquots for analyses were taken. Sample acidification to $\mathrm{pH} 3$ with ultrapure concentrated nitric acid was restricted to samples used for $\mathrm{P}$ analysis. All aliquots were stored at $8^{\circ} \mathrm{C}$.

To assess the mobilization and retention of $\mathrm{P}$ in water passing through canopy, forest floor and mineral soil, changes in concentrations and fluxes of $\mathrm{P}$ in bulk precipitation, throughfall, runoff from the forest floor $(\mathrm{ca} .0-15 \mathrm{~cm})$, and the upper mineral soil $(15-150 \mathrm{~cm})$ over time were compared. Only 17 samples could be collected from the deepest soil layer $(150-320 \mathrm{~cm})$, and thus, the temporal variability of $\mathrm{P}$ concentrations in this hydrological compartment was not assessed. Continuous time series of water levels were recorded at weirs at the outlet of the two catchments and at the groundwater well. Water levels in the weirs were transformed into discharge using discharge rating curves. From March to June 2015, three peaks in deep groundwater levels were not fully recorded, since the sensor (Ott Orpheus Water Level Logger) was placed too low and the maximum measureable head was exceeded.

\section{Analytical Methods}

Total P concentrations were measured in the "HELGES" Laboratory at GFZ Potsdam (von Blanckenburg et al., 2016) using a high resolution Inductively-Coupled-Plasma Mass Spectrometer (ICP-MS; Element 2, Thermo Fisher Scientific, Bremen, Germany). Tests prior to the measurements showed that matrix-matched calibration was not needed, since no significant matrix effects were observed in the concentration range of the major elements. Accuracy and precision of the $\mathrm{P}$ determination was assessed using two international reference standards (National Research Council of Canada, SLRS-5, and U.S. Geological Survey, M-212) as well as four laboratory standards resembling a typical river-water matrix containing major constituents (Ca, Mg, K, Si, Na, S, P) and trace constituents $(\mathrm{Cu}, \mathrm{Ni}, \mathrm{Zn}, \mathrm{Ti}$, and $\mathrm{Fe})$ prepared from single element standards. The overall uncertainty of the P measurement was below $10 \%$ for the encountered range of concentrations. Concentrations of $\mathrm{Ca}, \mathrm{Na}, \mathrm{K}, \mathrm{Mg}$, and $\mathrm{S}$ were analyzed at GFZ Potsdam using Inductively Coupled Plasma Optical Emission Spectrometer (ICP-OES; 720ES, Varian, Mulgrave, Australia) following the procedure described by Schuessler et al. (2016) with relative uncertainties better than $10 \%$. Concentrations of total dissolved carbon $(\mathrm{C})$ and nitrogen $(\mathrm{N})$, and dissolved inorganic carbon (DIC) were analyzed using a Shimadzu (Kyoto, Japan) Vcpn analyzer. DIC concentrations were all below the detection limit of $50 \mu \mathrm{g} \mathrm{l}^{-1}$. Thus, dissolved carbon concentrations are considered as organic carbon. Chloride was measured with an ion chromatograph (790 Personal IC, Metrohm, Filderstadt, Germany) at the Chair of Soil Ecology, University of Freiburg.

\section{Data Evaluation}

Due to its high aerodynamic roughness, the canopy was expected to act as an efficient aerosol trap. As a result, $\mathrm{P}$ derived from dry deposition should have increased the $\mathrm{P}$ concentration in throughfall compared to bulk precipitation. In addition, $\mathrm{P}$ may have been leached from leaves, pollen, insects, and microorganisms within the canopy. To estimate fluxes of wet and dry $\mathrm{P}$ deposition as well as canopy leaching, the canopy balance model of Ulrich (1983) was used. The model is based on three assumptions. First, dissolved sodium $(\mathrm{Na})$ in throughfall is only from wet deposition and leaching from atmospheric dust because $\mathrm{Na}$ is neither taken up nor released by the plant canopy in relevant amounts. Second, the relation between wet and dry deposition observed for $\mathrm{Na}$ is transferable to other elements, including $\mathrm{P}$. Third, the fraction of dissolved $\mathrm{P}$ in throughfall that is neither accounted for by dry or wet deposition must originate from foliar leaching. There was no general exclusion of outlier values. Only samples with visible particular contamination were excluded, which was mostly due to insects getting into the sampler.

To assess the contributions of different hydrological compartments to discharge, we performed an end member mixing analysis (EMMA) using the software package EMMAgeo in the R Environment (Dietze and Dietze, 2013). Three end members were identified by applying the annual average concentrations of eight elements/parameters ( $\mathrm{Ca}, \mathrm{Na}, \mathrm{K}, \mathrm{Mg}, \mathrm{S}$, $\mathrm{DOC}, \mathrm{Si}, \mathrm{Cl})$ from water from the forest floor $(0-15 \mathrm{~cm})$, the mineral soil $(15-320 \mathrm{~cm})$, and groundwater. The model was calibrated to daily time series of those elements in the discharge of the spring catchment. The application of the EMMA was restricted to the spring catchment for two reasons: First, given that the element concentrations of the end members were exclusively inferred from the spring catchment we refrained from transferring the data to the adjacent catchment for reasons of small-scale heterogeneity. Second, the simulation of instream transformation processes that likely occur in headwater catchments is beyond the scope of EMMA.

We then tested whether the calculated discharge contributions from soil- and groundwater (when considering the dissolved P concentrations in those compartments) would lead to a simulated $\mathrm{P}$ concentration in discharge that is similar to the one actually observed in spring discharge using simple linear regression analysis. In doing so, we could infer whether the sources of discharge imposed a control on discharge P contractions.

Similarity of temporal variation between data series was assessed with linear models using the $\operatorname{lm}($ ) function, and 2-sample $t$-tests for comparing group averages were assessed using the $t$ test function in R Environment (Dietze and Dietze, 2013). The raw data used in this study is partially available as a supplement to this study (Supplementary Table 1).

\section{RESULTS}

\section{Hydrological Conditions}

The hydrological conditions in the catchments during the study period were characterized by three distinct periods: Spring and summer until June 2015 were relatively wet, followed by a relatively dry period with a marked water deficit which ended in November 2015 and then by a period of rewetting, which extended into January 2016. With a precipitation sum of $1,118 \mathrm{~mm} \mathrm{a}^{-1}$ the study period was unusually dry compared 
to the long-term average annual precipitation of $1,749 \mathrm{~mm} \mathrm{a}^{-1}$ (average 1961-1996).

From March to June 2015, soil moisture, groundwater level and discharge fluxes responded rapidly to precipitation events (Figure 1), which suggested that in this period the hydrological compartments were well connected. In the groundwater well, a fill-and-spill behavior could be observed: At ground water levels between 8 and $6.3 \mathrm{~m}$ below the surface, relatively strong variability occurred corresponding to the occurrence of precipitation, but peaks of groundwater level consistently stopped at around $6.3 \mathrm{~m}$ below ground (Figure 1C). The groundwater table did not react immediately to precipitation events but with a lag time of 1-2 days. Still, until the beginning of June, all main discharge events in the creek and spring catchment were associated with corresponding changes of the groundwater table depth.

At the beginning of June 2015, soil moisture was only 5\% below that of the wetter spring period but strong hydrological changes were observed, indicating the start of the drier summer period: The rainfall-runoff event occurring mid of June produced smaller increases in discharge and soil moisture compared to events with similar amounts of precipitation in the previous months (Figures 1A,B,D). The groundwater seemed to be disconnected from precipitation events from the beginning of June until December. The slowly declining groundwater level indicated continuous drainage of the groundwater during this period. Small fluctuations in discharge occurred after precipitation events in both catchments, which were more pronounced in the creek catchment.

At the end of November and early December 2015, two large precipitation events occurred. The first event elevated soil moisture to pre-summer level and caused substantial discharge in both catchments. No groundwater recharge occurred after the first precipitation event, and the observable increase in the groundwater level was small even after the second precipitation event. Pre-summer groundwater levels were only reached as late as in January 2016. Thus, the rewetting took 1.5 months.
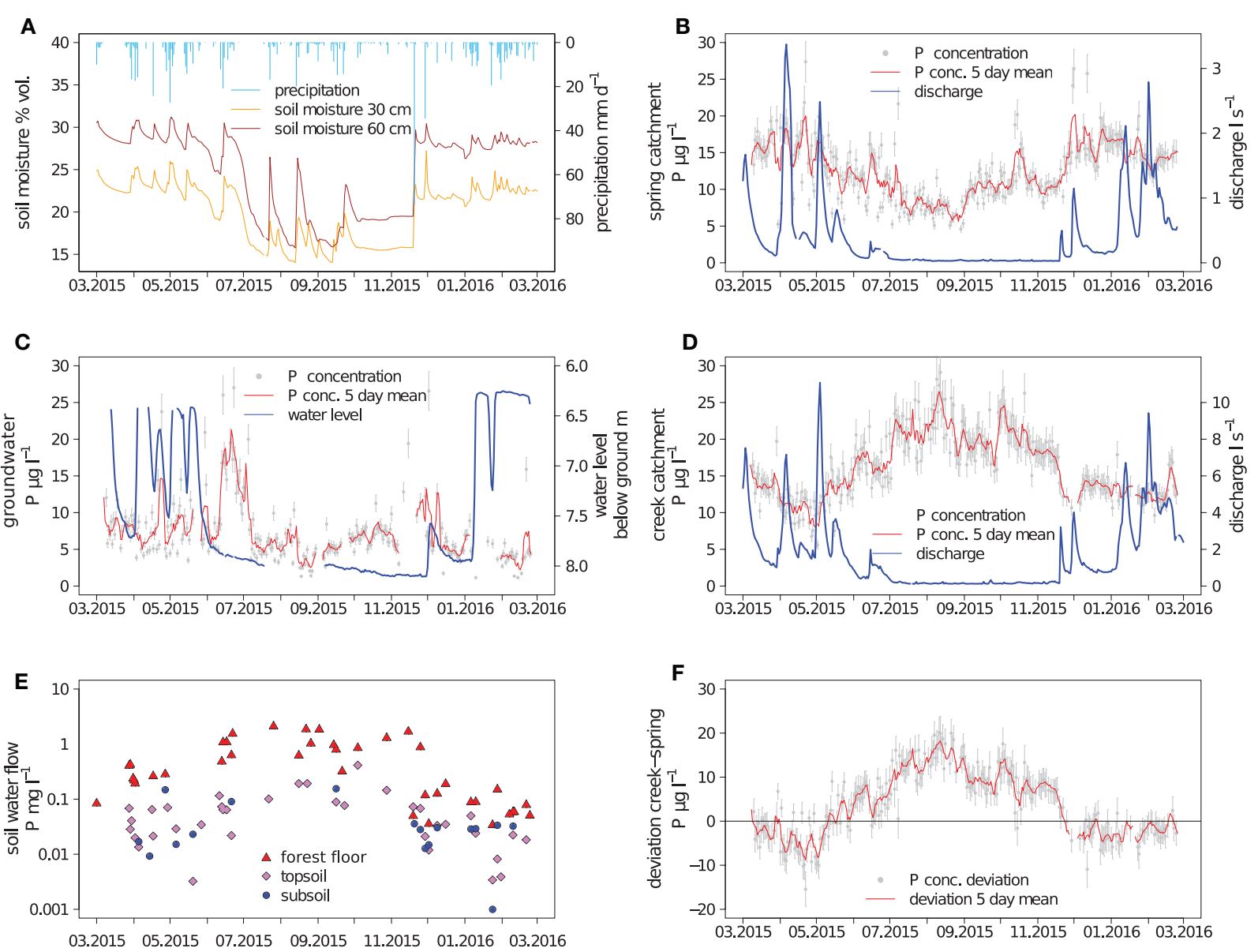

FIGURE 1 | Hydrological variables and phosphorus (P) concentrations; bulk precipitation and soil moisture (A). Discharge and dissolved $\mathrm{P}$ concentrations in the spring and creek catchment (B,D); water level and $P$ concentrations in the groundwater (C). $P$ concentrations of lateral subsurface flow $(\mathbf{E})$; deviation of $P$ concentration in discharge between the creek and spring catchment (F); depth intervals of subsurface flow were $0-15 \mathrm{~cm}$ (forest floor), 15-150 cm (upper mineral soil), and $150-320 \mathrm{~cm}$ (deeper mineral soil); uncertainty bars represent the standard deviation of the arithmetic mean. 


\section{Phosphorus Concentrations}

Phosphorus concentrations in bulk precipitation were on average $5.8 \mu \mathrm{g} \mathrm{l}^{-1}$ (Table 1). Relatively high $\mathrm{P}$ concentrations in bulk precipitation (>10 $\mathrm{g} \mathrm{I}^{-1}$ ) were found during the vegetation period, lower $\mathrm{P}$ concentrations $\left(<5 \mu \mathrm{g} \mathrm{l}^{-1}\right)$ in the dormant season. Phosphorus concentrations in throughfall were on average $140 \mu \mathrm{g} \mathrm{l}^{-1}$ and peaked from late summer to leaf abscission in autumn. Peak P concentrations in throughfall were $>1,000 \mu \mathrm{g}^{-1}$. Phosphorus concentrations in bulk precipitation and throughfall were not significantly correlated $(p>0.05$, not shown). Interestingly, the high throughfall fluxes of $\mathrm{P}$ from July to October appear to have been driven by increases in throughfall $\mathrm{P}$ concentrations rather than by high amounts of precipitation. Only $24 \%$ of the annual precipitation were recorded in this period but $71 \%$ of the total P flux with throughfall.

Disentangling the canopy $\mathrm{P}$ fluxes into wet and dry atmospheric deposition and canopy leaching by applying the canopy balance model (Ulrich, 1983) suggested that the vast majority of $\mathrm{P}$ fluxes with throughfall originated from foliar $\mathrm{P}$ leaching (Figures 2C,D). Within the first 3 months of the vegetation period after budbreak in April, no notable canopy leaching was detected. From July to November, canopy leaching steadily increased, with $\mathrm{P}$ fluxes higher than $10 \mathrm{mg} \mathrm{m}^{-2} \mathrm{month}^{-1}$ (Figures 2B,C). The highest wet and dry $\mathrm{P}$ depositions were found from April to August, with one outlier in February 2016 (Figure 2A).

For groundwater and discharge of the two catchments, nearly continuous series of daily samples could be collected. In groundwater, the average $\mathrm{P}$ concentration was $7 \mu \mathrm{g} \mathrm{l}^{-1}$,

TABLE 1 | Concentrations and fluxes of $\mathrm{P}$ and water in the study area.

\begin{tabular}{|c|c|c|c|}
\hline & \multicolumn{3}{|c|}{ concentration } \\
\hline & $\mu \mathrm{g} \mathrm{I}^{-1}$ (SD) & $\begin{array}{l}\mathrm{mg} \mathrm{m}^{-2} \mathrm{a}^{-1} \\
\text { (uncertainty) }\end{array}$ & $\mathrm{mm} \mathrm{m^{-2 }} \mathrm{a}^{-1}$ \\
\hline Bulk open precipitation & $5.9( \pm 10)$ & $7.4( \pm 1)$ & 944 \\
\hline $\begin{array}{l}\text { Bulk throughfall } \\
\text { precipitation }\end{array}$ & $150( \pm 24)$ & $60( \pm 6)$ & 769 \\
\hline Dry deposition & \multicolumn{3}{|c|}{$9.7(+2.4 /-2.0)^{\mathrm{a}}$} \\
\hline Canopy leaching & \multicolumn{3}{|c|}{$43(+8.8 /-9.2)^{a}$} \\
\hline Organic layer water flow & $570( \pm 600)$ & $0.001^{d}$ & $0.002^{d}$ \\
\hline Mineral soil & $43( \pm 38)$ & $20^{d}$ & $446^{d}$ \\
\hline Groundwater & $7.1( \pm 4.2)$ & $2.5^{\mathrm{d}}$ & $166^{d}$ \\
\hline Discharge spring & $13( \pm 4.0)$ & $9.2( \pm 1.0)^{\mathrm{C}}$ & $613^{c}$ \\
\hline Discharge creek & $16( \pm 4.5)$ & $7.9( \pm 1.0)$ & 613 \\
\hline $\begin{array}{l}\text { P Balance spring } \\
\text { catchment }\end{array}$ & \multicolumn{3}{|c|}{$7.8(+4.1 /-3.7)^{\mathrm{b}}$} \\
\hline $\begin{array}{l}\text { P Balance creek } \\
\text { catchment }\end{array}$ & \multicolumn{3}{|c|}{$9.1(+3.9 /-3.5)^{\mathrm{b}}$} \\
\hline
\end{tabular}

${ }^{a}$ Calculated according to Ulrich (1983).

${ }^{b}$ Bulk open prec.

+Dry deposition-discharge $P$ flux.

cIncluding ungagged below-ground discharge with total specific discharge assumed to be equal to creek catchment.

${ }^{d}$ Calculated with EMMA. showing no clear indication of systematic seasonal variation (Figure 1C). One period of higher $\mathrm{P}$ concentrations occurred in June 2015, with concentrations up to $25 \mu \mathrm{g} \mathrm{l}^{-1}$. Phosphorus concentrations in groundwater were not significantly correlated to concentrations and fluxes of $\mathrm{P}$ in lateral soil water flow at any depth increment or discharge ( $p>0.05$, not shown). Day-to-day variations of $\mathrm{P}$ concentrations in groundwater were in a similar range to those in discharge water.

Phosphorus concentrations in discharge in the spring were on average $12 \mu \mathrm{g} \mathrm{l}^{-1}$ and were significantly ( $p<0.05$, not shown) smaller than the average $\mathrm{P}$ concentration in the creek water of $16 \mu \mathrm{g} \mathrm{l}^{-1}$. Phosphorus concentrations in discharge water from the two catchments displayed a nearly inverse seasonal pattern: Creek $\mathrm{P}$ concentrations were elevated during the vegetation period (Figure 1F), when spring $\mathrm{P}$ concentrations show a seasonal minimum. Day-to-day variations of $\mathrm{P}$ concentrations in discharge water were comparable between the two catchments.

While almost every recorded precipitation event was associated with the generation of lateral flow in the forest floor, not all events could be sampled. Over the measurement period, 39 lateral flow events were sampled in the forest floor $(0-15 \mathrm{~cm}), 36$ events from the upper mineral soil $(15-150 \mathrm{~cm})$, and 17 samples from the deeper mineral soil $(150-320 \mathrm{~cm})$. With average concentrations of $700 \mu \mathrm{g} \mathrm{P}^{-1}$ and maximum concentrations as high as $1,500 \mu \mathrm{g} \mathrm{P}^{-1}$, near-surface lateral flow in the forest floor was significantly enriched in $\mathrm{P}$ compared to throughfall; the highest concentrations usually occurred during the vegetation period (Figure 1D). In the upper mineral soil $(15-150 \mathrm{~cm}), \mathrm{P}$ concentrations in lateral subsurface flow were significantly reduced by about one order of magnitude in comparison to lateral flow from the forest floor. Phosphorus concentrations in the deeper mineral soil at $150-320 \mathrm{~cm}$ were not significantly smaller than the concentrations in the upper mineral soil ( $p<0.05$, not shown).

\section{End Member Mixing Analysis}

During the high-flow period from March to June 2015, spring discharge was dominated by water with a solute composition (Ca, Na, K, Mg, S, Cl, DOC) matching best that of water from the mineral soil (top- and subsoil grouped together, $15-320 \mathrm{~cm}$ ) (Figures 3A,B), with a relative contribution to discharge of up to $90 \%$. During the summer low-flow period, groundwater became the dominant source of discharge with over 95\% discharge contribution, which was reversed again at the end of November after two large precipitation-runoff events, raising the fraction of water from the mineral soil in discharge to around $50 \%$ initially. According to the EMMA, water from the forest floor hardly contributed to the mixture with contributions of about $0.2 \%$. The model uncertainty, i.e., the ability of the model to simulate a mixture from the end members with an element composition matching the measured composition at a given day, was lowest in the high-flow period and highest in the low-flow period (Figure 3C).

Since the actual $\mathrm{P}$ concentrations of the end members are known but not included in the fitting process of the EMMA, it can be tested how well the actual $\mathrm{P}$ concentrations in 
A
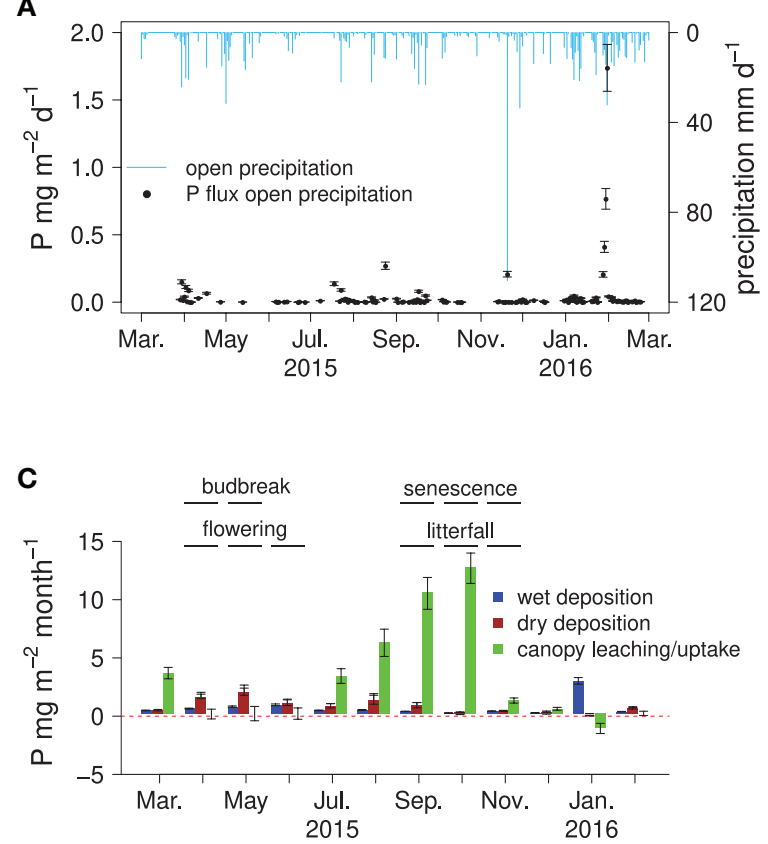

B

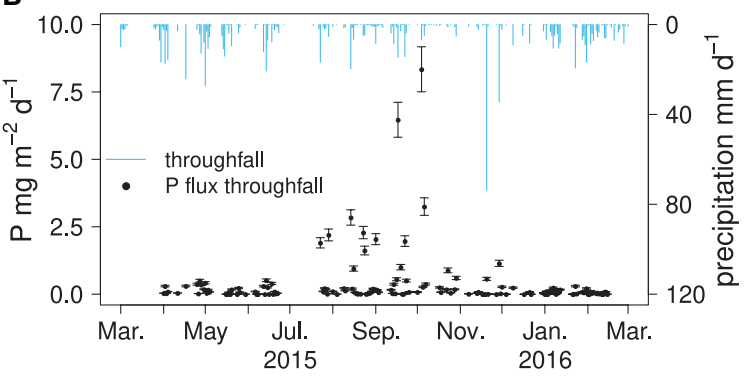

D 60

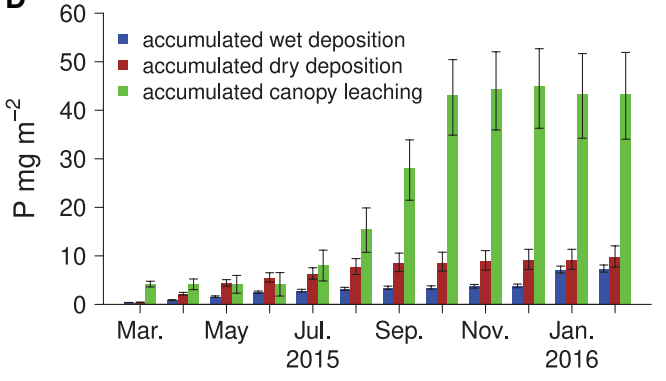

FIGURE 2 | Fluxes of $\mathrm{P}$ in bulk precipitation and throughfall, monthly, and accumulated atmospheric $\mathrm{P}$ deposition to the forest floor: daily fluxes of $\mathrm{P}$ in open precipitation (A) and throughfall (B), the canopy $\mathrm{P}$ balance with monthly fluxes of wet deposition, dry deposition, canopy leaching, and some phenological indicators measured on site (C), and accumulated fluxes of $P$ in wet deposition, dry deposition, and canopy leaching (D).

spring discharge can be simulated using the simulated end member composition. In doing so, it becomes apparent that the $\mathrm{P}$ concentration in spring discharge is systematically overestimated by the calculated end member composition (Figure 4). If the EMMA model uncertainty is used to weigh the data points for a linear regression between measured and simulated $\mathrm{P}$ concentrations in spring discharge, only a moderately good fit $\left(R^{2}=0.38\right)$ is achieved with a slope significantly larger than one (Figure 4D). Given that the model uncertainty is small in the low-flow period, the EMMA provides reliable results for this period. Also, weekly and seasonal variations in $\mathrm{P}$ concentrations in spring discharge are well-predicted by the EMMA. In summary, EMMA predicts that water from the mineral soil $(15-320 \mathrm{~cm})$ is the largest contributor to discharge (66\% over the whole observation period), followed by groundwater with $34 \%$ and water from the forest floor with only $0.02 \%$. For the $\mathrm{P}$ fluxes leaving the spring catchment, the differences are even more pronounced, with the mineral soil being the dominant source with $93 \%$, followed by groundwater with 6 and $0.5 \%$ from the forest floor (Figure 4E). The variability of discharge is much higher than the variability of $\mathrm{P}$ concentrations therein. Because of this, the bulk of the accumulated discharge $\mathrm{P}$ flux is confined to the highflow periods (Figure 4F). This also means, that discharge itself is a more accurate predictor for the discharge $\mathrm{P}$ flux than the associated $\mathrm{P}$ concentration, so that the temporal pattern of $\mathrm{P}$ fluxes can be somewhat accurately represented by our approach (Figures 4E,F).

\section{The P Balance of the Catchments}

Based on the results from the canopy balance and the EMMA, we calculated not only the mean annual $\mathrm{P}$ concentrations in the hydrological compartments, but also estimated the annual $\mathrm{P}$ fluxes that enter or leave the ecosystem as well as some that result from cycling within the ecosystem (Table 1). Disregarding mineral weathering for which we do not have direct measurements in this study, the P balance would be negative if only wet deposition is regarded as a true input to the ecosystem but clearly positive if dry deposition is regarded as input (Table 1). The uncertainties presented for the P fluxes (Table 1) represent the effect of the standard deviation of $\mathrm{P}$ measurements of individual samples on the calculated P fluxes. In the case of wet- and dry deposition the additional inclusion of the model uncertainty results in an asymmetric uncertainty range. The uncertainty for the catchment balances is the maximum range of uncertainty resulting from the individual balance components. Uncertainties for the measured water fluxes were not determined.

\section{DISCUSSION}

\section{P Inputs via Atmospheric Deposition}

The question whether the atmospheric dry deposition of $\mathrm{P}$ can be regarded as a true input to the site is of high relevance for the overall $\mathrm{P}$ balance. The answer depends on whether dry deposition in forests stems from external or internal sources. One possible internal source is pollen dispersion, which can contribute substantially to atmospheric dry P deposition (Doskey 

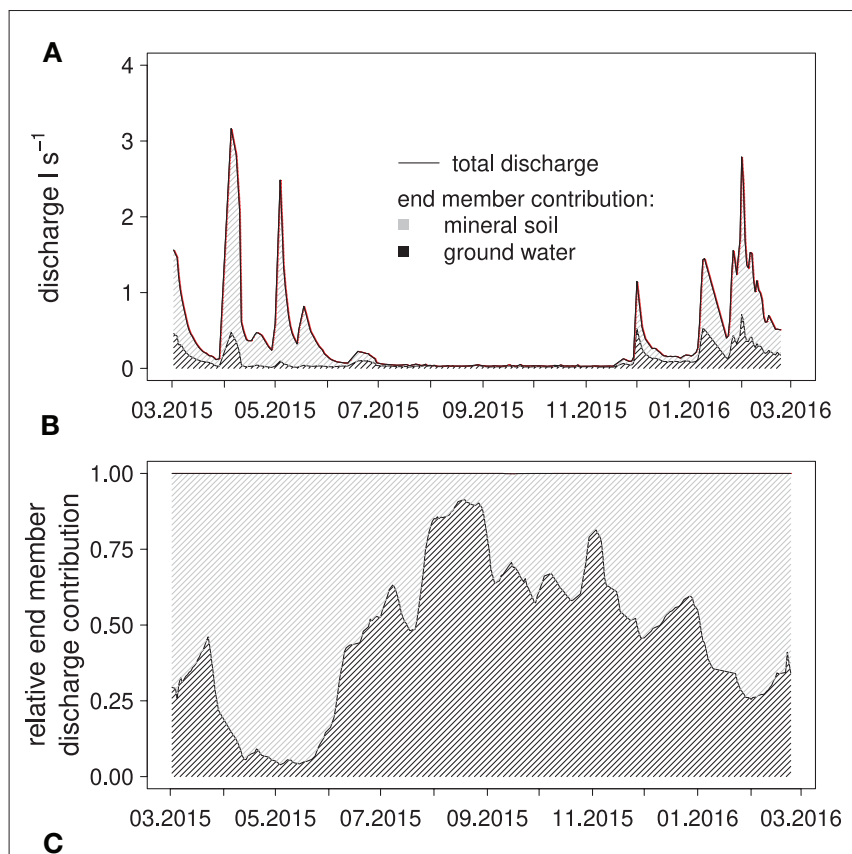

C

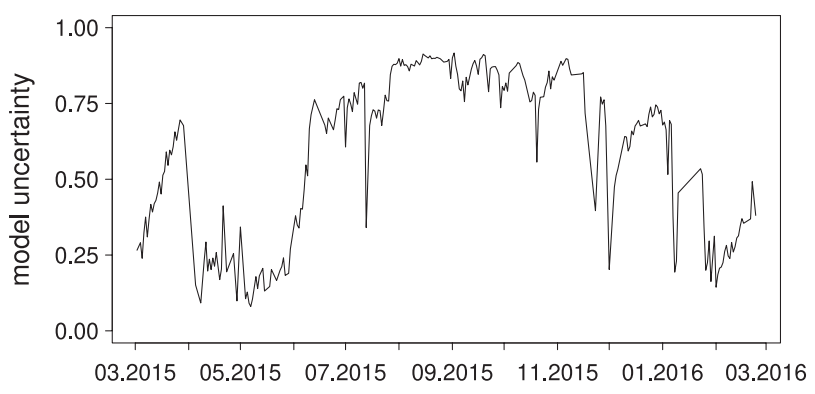

FIGURE 3 | Results of the EMMA: Calculated absolute contributions of the end members to spring discharge (A); water from the forest floor was used as an end member but ended up not contributing significant amounts to the simulated discharge composition, simulated, end member contributions to discharge (B) and relative model uncertainty (C).

and Ugoagwu, 1989; Tipping et al., 2014). The calculated high P dry deposition fluxes (May to June) at our study site intersect with the period of pollen dispersion (Figure 2C). Although their size of $10-100 \mu \mathrm{m}$ exceeds the pore size $(0.8 \mu \mathrm{m})$ of the used filters by 2-3 orders of magnitude, $\mathrm{P}$ might have been leached out of pollen increasing the $\mathrm{P}$ concentration in throughfall. However, we have to consider that pollen are not only entering the forest canopy, but are also exported from the forest. Therefore, without detailed investigation it is not clear whether a net $\mathrm{P}$ input or export occurs by pollen dispersion.

Further, the assumption of $\mathrm{Na}$ behaving conservatively during canopy passage underlying the canopy balance model of Ulrich (1983) has been challenged. In particular, it has been shown, that especially young (broad-) leaves do loose $\mathrm{Na}$ via foliar leaching (Tukey Jr, 1970; Staelens et al., 2007; Thimonier et al., 2008). Disregarding foliar leaching of $\mathrm{Na}$ could cause overestimation of dry deposition and underestimation of foliar leaching of $\mathrm{P}$ in the canopy balance model used in this study. The underestimation of foliar leaching could be small relative to the total foliar leaching of P. The estimate for dry deposition, however, could be more severely affected, since as much as $45 \%$ of throughfall $\mathrm{Na}$ enrichment may be due to foliar leaching (Thimonier et al., 2008).

Foliar P leaching dominates the overall canopy $\mathrm{P}$ balances of our catchments. Direct evidence of foliar P leaching is still lacking in the literature and indirect estimates of foliar P leaching are much lower than the amount derived from this study, ranging from a maximum of $20 \mathrm{mg} \mathrm{m}^{-2} \mathrm{a}^{-1}$ to net uptake of $\mathrm{P}$ into the foliage during canopy passage (Long et al., 1956; Tukey Jr, 1966; Miller et al., 1976; Duquesnay et al., 2000; Kopavcek et al., 2009; Runyan et al., 2013). At $50 \mathrm{mg} \mathrm{m}^{-2} \mathrm{a}^{-1}$, the calculated foliar leaching flux of $\mathrm{P}$ in this study translates into about $10 \%$ of the average total $\mathrm{P}$ content in mature leaves of a deciduous forest (Sohrt et al., 2017). This implies, that foliar resorption of $\mathrm{P}$, which is generally assumed to be solely responsible for the deviation of the $\mathrm{P}$ content in mature foliage and foliar litterfall (Killingbeck, 1986, 1996; Duchesne et al., 2001; Côté et al., 2002), may generally be overestimated if foliar leaching is assumed to be negligible.

Leaching of $\mathrm{P}$ from the canopy was virtually absent in the first 3 months of the vegetation period. This implies that young leaves are able to avoid significant losses of $\mathrm{P}$ via leaching. Two months before the first indications of leaf senescence occurred, leaching of $\mathrm{P}$ from the canopy was already significantly increased, which means the leaves lose $\mathrm{P}$ in their later life cycle. Almost half of the total throughfall deposition is due to leaching from the canopy during the first 2 months of leaf senescence. The increase in leaching from the canopy may be due to the stepwise reduction in leaf functionality during senescence, causing the leaves to become more "leaky." In addition, progressing microbial degradation of the senescent foliage may come into effect: The relevant decomposer organisms are already present on the foliar surfaces before senescence and generally become active before leaf abscission (Snajdr et al., 2011). This could cause damage to the leaves and subsequent leaching of soluble substances with throughfall, although the initial binding form of leached $\mathrm{P}$ was not addressed in this study. Interestingly, during the last month of leaf senescence (November), the $\mathrm{P}$ foliar leaching decreased again to very small fluxes, although precipitation amounts stayed constant and leaf abscission was only completed by the end of November after a rainstorm event. Hence, the bulk of foliar P leaching occurs before the final stages of senescence Besides below-average amounts of bulk open precipitation there was no apparent occurrence of vegetation stressors such as pests or strong storm events. Potential sources of $\mathrm{P}$ inputs are arable fields in the Rhine valley or the City of Freiburg just $7 \mathrm{~km}$ west of the study site. Considering also the predominant westerly winds in the area, deposition of P-rich dust from agricultural and urban settings is, hence, the most likely cause for the $\mathrm{P}$ enrichment in throughfall water.

\section{End Member Mixing Analysis}

It is apparent that the EMMA performed best during the low-flow period, when calculated groundwater contribution to discharge was high, and worse during high-flow periods, when water from the mineral soil was the dominant source of discharge water. This indicated that the sampled groundwater body directly 
A

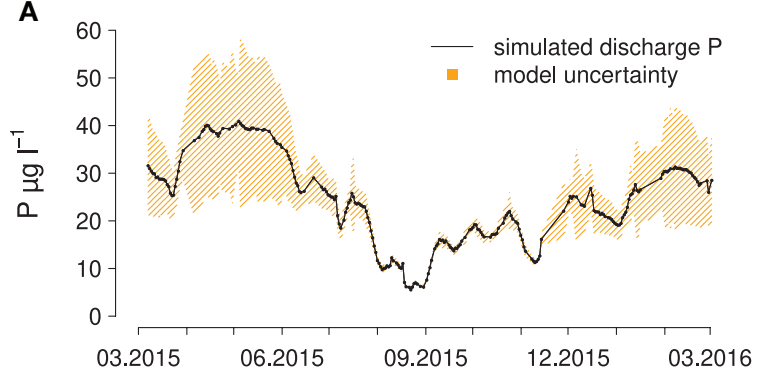

C

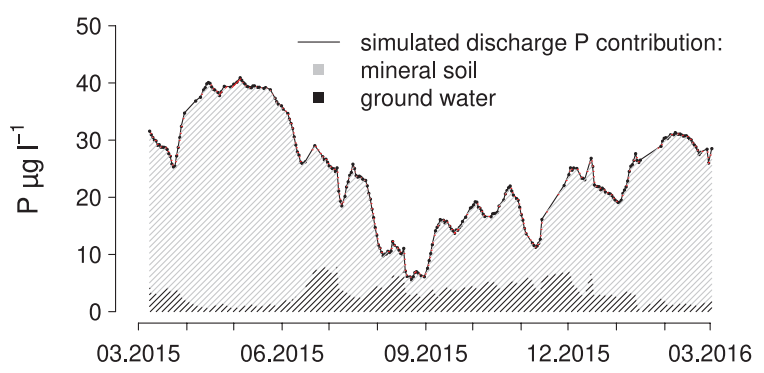

E

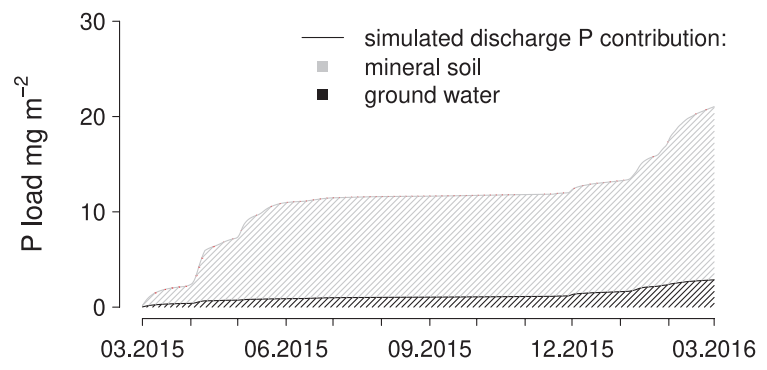

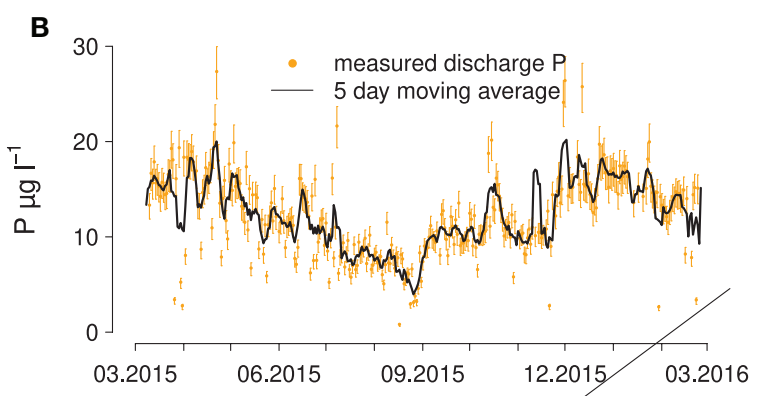
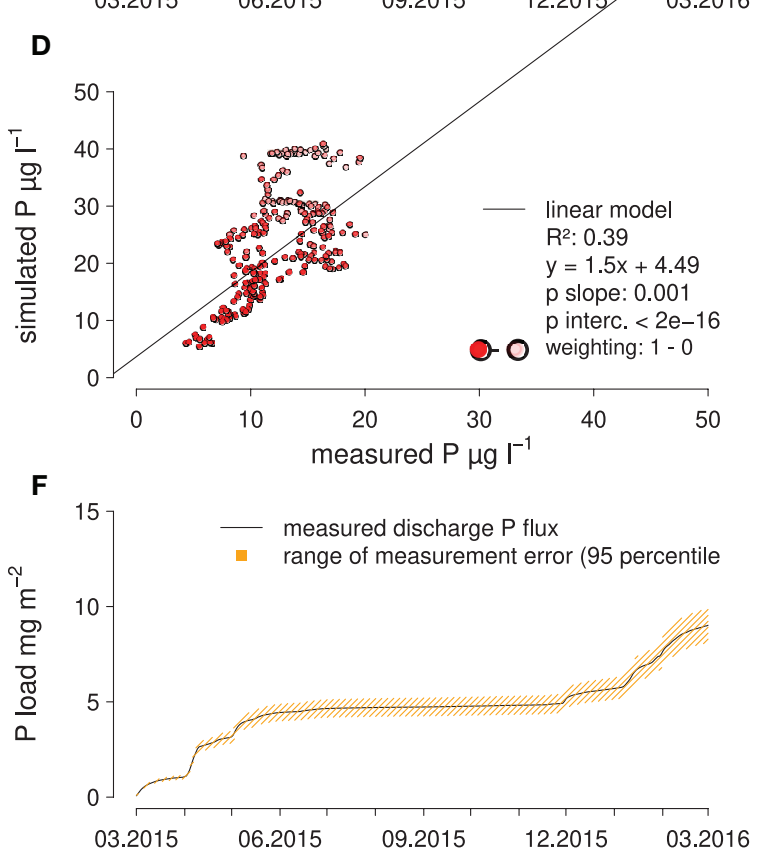

FIGURE 4 | Results of EMMA compared to measured data: simulated (A) and measured (B) discharge P concentrations, contribution of end members to simulated discharge $P$ concentrations (C), scatter plot of measured vs. simulated discharge P concentrations (D), as well as simulated (E), and measured (F) cumulative $P$

fluxes in the creek catchment.

contributes to discharge without large changes in chemical composition, and thus, was a suitable end member. Water from the forest floor, on the other hand, was almost absent from the mixtures calculated with the EMMA, meaning that it likely did not contribute to spring discharge at all. The reason was likely that the spring lacked a sufficiently long interception interface with the thin forest floor, in contrast to more linear creeks for example.

Overall, water from the mineral soil was responsible for $65 \%$ of total discharge according to the EMMA. Periods with higher fractions of soil water in discharge were consistently associated with higher model uncertainties. From these results it can be deduced that our model was missing an important end member that presumably contributed large parts of discharge during highflow events. A possible candidate would be water from soil layers below our maximum sampling depth.

When simulating discharge P concentrations in the spring catchment from the end member contributions suggested by the EMMA, P concentrations were strongly overestimated during the high-flow period in spring when the model inaccuracy was also highest. During the rest of the study period, discharge $\mathrm{P}$ concentrations are still overestimated but less pronounced. The reason for the systematic overestimation could be the fact that $\mathrm{P}$ is known to easily attach to or react with a variety of soil components, while the elements that were used to calibrate the EMMA may behave more conservatively. The fact that $\mathrm{P}$ concentrations in subsurface flow declined sharply with increasing depth across the sampled soil layers implies that, at least in those layers, $\mathrm{P}$ immobilization by sorption took place. Still, simulated discharge $P$ concentrations are significantly correlated to measured concentrations, which suggests that changes in discharge contribution of different water sources are an important control of $\mathrm{P}$ concentrations in spring discharge.

\section{Deviations of Discharge P Concentrations Between the Two Catchments}

We identified contrary seasonal variations in discharge $\mathrm{P}$ concentrations in the creek and the spring catchment, although 
the adjacent catchments are similar in topography, soil type, lithology, and vegetation cover. The only difference is that the creek catchment has an open channel bed, which is absent in the spring catchment. Here we provide two potential reasons explaining the difference.

The first is that an open channel bed has the potential to receive discharge contributions directly from precipitation and surface runoff, which would be absent for spring discharge. Since throughfall, surface runoff, and shallow subsurface flow are highly enriched in $\mathrm{P}$ compared to groundwater, significant inputs of water via these flow paths should control the P concentrations in spring discharge. Given that these flow paths should contribute relatively more water to discharge in the creek than in the spring, larger average $\mathrm{P}$ concentrations and larger temporal variations of $\mathrm{P}$ concentrations would be expected for the creek compared to spring, especially during rainfall-runoff events. However, $\mathrm{P}$ concentrations in the creek water were highest in the dry period (with lacking near surface runoff) and there were no increases in discharge $\mathrm{P}$ with rainfall-runoff events. Consequently, there were no indications of near-surface runoff being the controlling pathway of $\mathrm{P}$ export at the study site for either of the two sites.

The second possible explanation of the difference in seasonal variations in discharge $\mathrm{P}$ between the creek and the spring catchment were in-stream transformation processes. It has been demonstrated that retention of $\mathrm{P}$ by in-stream biomass can strongly affect variations in discharge P: Periphyton growth is associated with uptake of discharge $\mathrm{P}$ in spring until leaf flushing (Friberg et al., 1997; Mulholland and Hill, 1997; Hill et al., 2001; Winkelmann et al., 2014). Heterotrophic microbial growth on leaf litter entering the stream can cause a similar effect in autumn and winter since these microbes are initially $\mathrm{N}$ - and $\mathrm{P}$ - rather than C-limited (Gregory, 1978; Munn and Meyer, 1990; Bernhardt and Likens, 2002; Rier and Stevenson, 2002; Stelzer et al., 2003; Mulholland, 2004; Hill et al., 2010). During summer, periphyton activity is decreased due to shading by trees, and P limitation of in-stream heterotrophic decomposers may be reduced, as the litter from the previous autumn is increasingly depleted of accessible $\mathrm{C}$ sources. In this time, the in-stream biomass may become a source of discharge $\mathrm{P}$ rather than being a sink. Since the seasonal pattern of $\mathrm{P}$ concentrations in the creek is in line with this concept, it seems probable that the deviation in $\mathrm{P}$ concentrations in discharge between the two studied catchments is due to biotic P turnover in the creek, which would be mostly absent in the spring discharge, leading to the observed differences in the seasonal pattern of $\mathrm{P}$ concentrations in discharge between the two catchments.

\section{P Balance of the Study Area}

In line with earlier studies on the subject (e.g., Cole and Rapp, 1981; Sohrt et al., 2017), the analysis of P fluxes in bulk precipitation and throughfall in combination with the application of the Ulrich (1983) canopy balance model suggested that atmospheric $\mathrm{P}$ inputs alone might compensate $\mathrm{P}$ losses with drainage and runoff in temperate forests. However, especially the estimated dry deposition flux is connected with uncertainties. The $\mathrm{P}$ discharge flux quantified in this study allows for a comparison with the study site's $\mathrm{P}$ weathering flux determined by
Uhlig and von Blanckenburg (2019a) amounting to $76 \pm 17 \mathrm{mg}$ $\mathrm{m}^{-2} \mathrm{a}^{-1}$. This flux exceeds the $\mathrm{P}$ discharge flux presented in this study by an order of magnitude. As the integration timescales for cosmogenic nuclide-derived weathering fluxes $\left(10^{3}-10^{5}\right.$ year $)$ and gauging-derived discharge fluxes $\left(10^{0}-10^{1}\right.$ year $)$ differ by orders of magnitudes, timescale effects could account for this discrepancy. Since bulk precipitation during the study period was only $60 \%$ of the 30 -year average, the mean annual discharge, and thus, $\mathrm{P}$ export was likely less than usual. However, accounting for timescale effects by normalizing the respective $\mathrm{P}$ fluxes to fluxes of sodium does not eliminate the discrepancy between the $\mathrm{P}$ discharge flux and the $\mathrm{P}$ weathering flux (unpublished data). Sodium was chosen because $\mathrm{Na}$ is an "inert" element with respect to nutrient uptake and neoformation of secondary minerals during chemical weathering. Such discrepancy, quantifiable through a metric called sodium normalized "dissolved export efficiency” (DEE ${ }_{\mathrm{Na}}^{\mathrm{X}}$, Uhlig et al., 2017; Schuessler et al., 2018) can be observed across the globe (Uhlig et al., 2017; Schuessler et al., 2018). Potential fluxes of $P$ that could (in combination) explain this systematic discrepancy include underestimated $\mathrm{P}$ exports with litter and wood (de Oliveira Garcia et al., 2018), transiently increasing $\mathrm{P}$ stocks in biomass in growing forests, and net $\mathrm{P}$ export via pollen dispersion.

It appears that the sum of $\mathrm{P}$ release from weathering (Uhlig and von Blanckenburg, 2019a) together with atmospheric P inputs determined in this study likely compensate P losses with runoff. Therefore, declining foliar $\mathrm{P}$ levels are unlikely the result of a $\mathrm{P}$ depletion of the forest ecosystem.

\section{CONCLUSIONS}

The common observation, that percolating water becomes strongly enriched in dissolved $\mathrm{P}$ during the passage through the canopy and the forest floor, where the highest $\mathrm{P}$ concentrations are recorded, was confirmed by this study. This trend was found to be reversed when the water came into contact with the mineral soil, where dissolved $\mathrm{P}$ was effectively retained, causing the $\mathrm{P}$ concentration in soil water at about $3 \mathrm{~m}$ depth to be en par with that in the creek water. $\mathrm{P}$ export from the catchment via spring water was found to be driven by runoff from mineral soils and by groundwater discharge. Also in the investigated creek, a potential contribution of near-surface runoff to $\mathrm{P}$ exports appeared to be negligible or superimposed by in-stream $\mathrm{P}$ cycling.

Wet and dry deposition were found to be in a similar range. Even if only wet deposition was assumed to be a true input into the ecosystem, it outweighed the losses by discharge at our study site, so that the overall $\mathrm{P}$ balance of both catchments was positive during the study period. Together with the potential inflow of $\mathrm{P}$ through mineral weathering this supports the idea that declining foliar P levels of forest ecosystems are unlikely to be related to a declining total $\mathrm{P}$ supply, but rather to imbalances of tree nutrition, e.g., due to nitrogen fertilization, or alternative stressors, such as drought. Detailed investigations of atmospheric $\mathrm{N}$ and $\mathrm{P}$ deposition and the inclusion of fluxes resulting from mineral weathering are necessary to reduce major uncertainties of forest $\mathrm{P}$ budgets. 


\section{DATA AVAILABILITY STATEMENT}

All datasets for this study are included in the article/Supplementary Material.

\section{AUTHOR CONTRIBUTIONS}

JSo and MW conceived and designed the experiment. JSo was responsible for installation of field equipment, sampling, the integrative data analyses and visualization. DF, DU, FB, FL, JK, $\mathrm{KK}$, and SS contributed analyses and data. JSo conceptualized and wrote the paper as lead author. All authors contributed to the interpretation of the findings and the final manuscript.

\section{FUNDING}

This study was carried out under a grant from the DFGfunded project SPP 1685 Ecosystem Nutrition-Forest Strategies for Limited Phosphorus Resources (DFG WE 4598/7-1).

\section{REFERENCES}

Achat, D. L., Pousse, N., Nicolas, M., Brédoire, F., and Augusto, L. (2016). Soil properties controlling inorganic phosphorus availability: general results from a national forest network and a global compilation of the literature. Biogeochemistry 127, 255-272. doi: 10.1007/s10533-015-0178-0

Bachmair, S., and Weiler, M. (2012). Technical Report on Experimental Hillslope Hydrology, Hydronotes. University of Freiburg, Freiburg, Germany

Baldwin, D. S. (1999). Dissolved organic matter and phosphorus leached from fresh and 'terrestrially'aged river red gum leaves: implications for assessing river-floodplain interactions. Freshw. Biol. 41, 675-685. doi: 10.1046/j.1365-2427.1999.00404.x

Benning, R., Schua, K., Schwärzel, K., and Feger, K. (2012). Fluxes of nitrogen, phosphorus, and dissolved organic carbon in the inflow of the lehnmühle reservoir (Saxony) as compared to streams draining three main land-use types in the catchment. Adv. Geosci. 32, 1-7. doi: 10.5194/adgeo-32-1-2012

Bergkemper, F., Schöler, A., Engel, M., Lang, F., Krüger, J., Schloter, M., et al. (2016). Phosphorus depletion in forest soils shapes bacterial communities towards phosphorus recycling systems. Environ. Microbiol. 18, 1988-2000. doi: $10.1111 / 1462-2920.13188$

Bernal, S., Lupon, A., Ribot, M., Sabater, F., and Martí, E. (2015). Riparian and instream controls on nutrient concentrations and fluxes in a headwater forested stream. Biogeosciences 12, 1941-1954.

Bernhardt, E. S., and Likens, G. E. (2002). Dissolved organic carbon enrichment alters nitrogen dynamics in a forest stream. Ecology 83, 1689-1700. doi: 10. 1890/0012-9658(2002)083[1689:DOCEAN]2.0.CO;2

Bol, R., Julich, D., Brödlin, D., Siemens, J., Kaiser, K., Dippold, M. A., et al. (2016). Dissolved and colloidal phosphorus fluxes in forest ecosystems-an almost blind spot in ecosystem research. J. Plant Nutr. Soil Sci. 179, 425-438. doi: 10.1002/jpln.201600079

Brown, A. H. F., and Iles, M. A. (1991). Water chemistry profiles under four tree species at Gisburn, NW England. Forestry 64, 169-187. doi: 10.1093/forestry/64.2.169

Buendia, C., Kleidon, A., and Porporato, A. (2010). The role of tectonic uplift, climate, and vegetation in the long-term terrestrial phosphorous cycle. Biogeosciences 7, 2025-2038. doi: 10.5194/bg-7-2025-2010

Côté, B., Fyles, J. W., and Djalilvand, H. (2002). Increasing $\mathrm{N}$ and $\mathrm{P}$ resorption efficiency and proficiency in northern deciduous hardwoods with decreasing foliar $\mathrm{N}$ and $\mathrm{P}$ concentrations. Ann. For. Sci. 59, 275-281. doi: $10.1051 /$ forest:2002023

Cole, D. W., and Rapp, M. O. (1981). "Elemental cycling in forest ecosystems," in Dynamic Properties of Forest Ecosystems, ed D. E. Reichele (Cambridge: Cambridge University Press), 341-409.

\section{ACKNOWLEDGMENTS}

We are thankful for the data contributions from the Federal Forest Research Institute of Baden-Württemberg (Heike Puhlmann, FVA Freiburg). We acknowledge Jutta Schlegel, Ruth Magh, Franziska Zieger, and Lisa Dankwerth for sample management. Measurements for DOC were carried out by Christine Krenekwitz (Soil Science and Soil Protection, Martin Luther University Halle-Wittenberg), CL was measured by Petra Wiedemer and Nicole Specht (Soil Ecology, University of Freiburg).

\section{SUPPLEMENTARY MATERIAL}

The Supplementary Material for this article can be found online at: https://www.frontiersin.org/articles/10.3389/ffgc.2019. 00085/full\#supplementary-material

Supplementary Table 1 | Water fluxes and elemental concentrations at the Conventwald research site 2014-2016.

Compton, J. E., and Cole, D. W. (1998). Phosphorus cycling and soil P fractions in douglas-fir and red alder stands. For. Ecol. Manag. 110, 101-112. doi: 10.1016/S0378-1127(98)00278-3

de Oliveira Garcia, W., Amann, T., and Hartmann, J. (2018). Increasing biomass demand enlarges negative forest nutrient budget areas in wood export regions. Sci. Rep. 8:5280. doi: 10.1038/s41598-018-22728-5

Dietze, M., and Dietze, E. (2013). EMMAgeo: End-Member Modelling Algorithm and Supporting Functions for Grain-Size Analysis. R package version 0.9. 0.

Dillon, P. J., and Kirchner, W. (1975). The effects of geology and land use on the export of phosphorus from watersheds. Water Res. 9, 135-148. doi: 10.1016/0043-1354(75)90002-0

Doskey, P. V., and Ugoagwu, B. J. (1989). Atmospheric deposition of macronutrients by pollen at a semi-remote site in northern Wisconsin. Atmos. Environ. 23, 2761-2766. doi: 10.1016/0004-6981(89) 90556-8

Duchesne, L., Ouimet, R., Camiré, C., and Houle, D. (2001). Seasonal nutrient transfers by foliar resorption, leaching, and litter fall in a northern hardwood forest at lake clair watershed, quebec, Canada. Can. J. For. Res. 31, 333-344. doi: $10.1139 / \mathrm{x} 00-183$

Duquesnay, A., Dupouey, J., Clement, A., Ulrich, E., and Le Tacon, F. (2000). Spatial and temporal variability of foliar mineral concentration in beech (Fagus sylvatica) stands in northeastern France. Tree Physiol. 20, 13-22. doi: 10.1093/treephys/20.1.13

Elser, J. J., Bracken, M. E. S., Cleland, E. E., Gruner, D. S., Harpole, W. S., Hillebrand, H., et al. (2007). Global analysis of nitrogen and phosphorus limitation of primary producers in freshwater, marine and terrestrial ecosystems. Ecol. Lett.10, 1135-1142. doi: 10.1111/j.1461-0248.2007.01113.x

Elser, J. J., Fagan, W. F., Denno, R. F., Dobberfuhl, D. R., Folarin, A., Huberty, A., et al. (2000). Nutritional constraints in terrestrial and freshwater food webs. Nature 408, 578-580. doi: 10.1038/35046058

Elwood, J. W., Newbold, J. D., O’Neill, R. V., and Van Winkle, W. (1983). "Resource spiralling: an operational paradigm for analyzing lotic ecosystems," in Dynamics of Lotic Ecosystems, eds T. D. Fontaine III and S. M. Bartell (Ann Arbor, MI: Ann Arbor Science), 3-27.

Friberg, N., Winterbourn, M., Shearer, K., and Larsen, S. (1997). Benthic communities of forest streams in the South Island, New Zealand: effects of forest type and location. Arch. Hydrobiol. 138, 289-306.

Gosz, J. R., Likens, G. E., and Bormann, F. H. (1973). Nutrient release from decomposing leaf and branch litter in the hubbard brook forest, New Hampshire. Ecol. Monogr. 43, 173-191. doi: 10.2307/1942193

Gottselig, N., Nischwitz, V., Meyn, T., Amelung, W., Bol, R., Halle, C., et al. (2017). Phosphorus binding to nanoparticles and colloids in forest stream waters. Vadose Zone J. 16, 1-12. doi: 10.2136/vzj2016.07.0064 
Gregory, S. V. (1978). Phosphorus dynamics on organic and inorganic substrates in streams. Int. Ver. Theor. Angew. Limnol. Verh 20, 1340-1346. doi: $10.1080 / 03680770.1977 .11896696$

Hangen, E., Lindenlaub, M., Leibundgut, C., and Von Wilpert, K. (2001). Investigating mechanisms of stormflow generation by natural tracers and hydrometric data: a small catchment study in the black forest, Germany. Hydrol. Process. 15, 183-199. doi: 10.1002/hyp.142

Heuck, C., Weig, A., and Spohn, M. (2015). Soil microbial biomass C: N: P stoichiometry and microbial use of organic phosphorus. Soil Biol. Biochem. 85, 119-129. doi: 10.1016/j.soilbio.2015.02.029

Hill, B. H., McCormick, F. H., Harvey, B. C., Johnson, S. L., Warren, M. L., and Elonen, C. M. (2010). Microbial enzyme activity, nutrient uptake and nutrient limitation in forested streams. Freshwater Biol. 55, 1005-1019. doi: $10.1111 /$ j.1365-2427.2009.02337.x

Hill, W. R., Mulholland, P. J., and Marzolf, E. R. (2001). Stream ecosystem responses to forest leaf emergence in spring. Ecology 82, 2306-2319. doi: 10. 1890/0012-9658(2001)082[2306:SERTFL]2.0.CO;2

Horwath, W. R. (2017). "The role of the soil microbial biomass in cycling nutrients," in Microbial Biomass: A Paradigm Shift in Terrestrial Biogeochemistry, ed K. R. Tate (London: World Scientific), 41-66.

Ilg, K., Wellbrock, N., and Lux, W. (2009). Phosphorus supply and cycling at long-term forest monitoring sites in Germany. Eur. J. For. Res. 128, 483-492. doi: 10.1007/s10342-009-0297-z

Jansson, M., Persson, G., and Broberg, O. (1986). Phosphorus in acidified lakes: the example of lake gårdsjön, Sweden. Hydrobiologia 139, 81-96. doi: $10.1007 /$ BF00770243

Jonard, M., Fürst, A., Verstraeten, A., Thimonier, A., Timmermann, V., Potočić, N., et al. (2014). Tree mineral nutrition is deteriorating in Europe. Glob. Chang. Biol. 21, 418-430 doi: 10.1111/gcb.12657

Kaiser, K., Guggenberger, G., Haumaier, L., and Zech, W. (2001a). Seasonal variations in the chemical composition of dissolved organic matter in organic forest floor layer leachates of old-growth Scots pine (Pinus sylvestris L.) and European beech (Fagus sylvatica L.) stands in northeastern Bavaria, Germany. Biogeochemistry 55, 103-143. doi: 10.1023/A:1010694032121

Kaiser, K., Guggenberger, G., and Zech, W. (2001b). Organically bound nutrients in dissolved organic matter fractions in seepage and soil water of weakly developed forest soils. Acta. Hydrochim. Hydrobiol. 28, 411-419. doi: 10.1002/1521-401X(20017)28:7<411::AID-AHEH411>3.0.CO;2-D

Killingbeck, K. T. (1986). Litterfall dynamics and element use efficiency in a Kansas gallery forest. Am. Midl. Nat. 116, 180-189. doi: 10.2307/2425950

Killingbeck, K. T. (1996). Nutrients in senesced leaves: keys to the search for potential resorption and resorption proficiency. Ecology 77, 1716-1727. doi: $10.2307 / 2265777$

Kohler, M., Wilpert, K., and Hildebrand, E. (2000). The soil skeleton as a source for the short-term supply of base cations in forest soils of the black forest (Germany). Water Air Soil Pollut. 122, 37-48. doi: 10.1023/A:1005277909113

Kopavcek, J., Turek, J., Hejzlar, J., and Santruckova, H. (2009). Canopy leaching of nutrients and metals in a mountain spruce forest. Atmos. Environ. 43, 5443-5453. doi: 10.1016/j.atmosenv.2009.07.031

Laliberté, E., Grace, J. B., Huston, M. A., Lambers, H., Teste, F. P., Turner, B. L., et al. (2013). How does pedogenesis drive plant diversity? Trends Ecol. Evol. 28, 331-340. doi: 10.1016/j.tree.2013.02.008

Lang, F., Bauhus, J., Frossard, E., George, E., Kaiser, K., Kaupenjohann, M., et al. (2016). Phosphorus in forest ecosystems: new insights from an ecosystem nutrition perspective. J. Plant Nutr. Soil Sci. 179, 129-135. doi: $10.1002 /$ jpln.201500541

Lang, F., Krüger, J., Amelung, W., Willbold, S., Frossard, E., Bünemann, E. K., et al. (2017). Soil phosphorus supply controls P nutrition strategies of beech forest ecosystems in Central Europe. Biogeochemistry 136, 5-29. doi: 10.1007/s10533-017-0375-0

Long, W., Sweet, D., and Tukey, H. (1956). Loss of nutrients from plant foliage by leaching as indicated by radioisotopes. Science 123, 1039-1040. doi: 10.1126/science.123.3206.1039-a

Magh, R.-K., Grün, M., Knothe, V. E., Stubenazy, T., Tejedor, J., Dannenmann, M., et al. (2017). Silver-fir (Abies alba MILL.) neighbors improve water relations of European beech (Fagus sylvatica L.), but do not affect N nutrition. Trees 32, 337-348. doi: 10.1007/s00468-017-1557-z
Mahowald, N., Jickells, T. D., Baker, A. R., Artaxo, P., Benitez-Nelson, C. R., Bergametti, G., et al. (2008). Global distribution of atmospheric phosphorus sources, concentrations and deposition rates, and anthropogenic impacts. Glob. Biogeochem. Cycles 22:4026. doi: 10.1029/2008GB003240

Meyer, J. L., and Likens, G. (1979). Transport and transformation of phosphorus in a forest stream ecosystem. Ecology 60, 1255-1269.

Miller, H., Cooper, J. M., and Miller, J. (1976). Effect of nitrogen supply on nutrients in litter fall and crown leaching in a stand of Corsican pine. J. Appl. Ecol. 13, 233-248. doi: 10.2307/2401943

Missong, A., Bol, R., Nischwitz, V., Krüger, J., Lang, F., Siemens, J., et al. (2017). Phosphorus in water dispersible-colloids of forest soil profiles. Plant Soil 427, 71-86. doi: 10.1007/s11104-017-3430-7

Missong, A., Bol, R., Willbold, S., Siemens, J., and Klumpp, E. (2016). Phosphorus forms in forest soil colloids as revealed by liquid-state 31P-NMR. J. Plant Nutr. Soil Sci. 179, 159-167. doi: 10.1002/jpln.201500119

Mulholland, P. J. (1992). Regulation of nutrient concentrations in a temperate forest stream: roles of upland, riparian, and instream processes, Limnol. Oceanogr. 37:1512-1526. doi: 10.4319/lo.1992.37.7.1512

Mulholland, P. J. (2004). The importance of in-stream uptake for regulating stream concentrations and outputs of $\mathrm{N}$ and $\mathrm{P}$ from a forested watershed: evidence from long-term chemistry records for walker branch watershed. Biogeochemistry 70, 403-426. doi: 10.1007/s10533-0040364-y

Mulholland, P. J., and Hill, W. R. (1997). Seasonal patterns in streamwater nutrient and dissolved organic carbon concentrations: separating catchment flow path and in-stream effects. Water Resour. Res. 33, 1297-1306. doi: 10.1029/97WR00490

Mulholland, P. J., Newbold, J. D., Elwood, J. W., and Webster, J. R. (1985). Phosphorus spiralling in a woodland stream: seasonal variations. Ecology 66, 1012-1023. doi: $10.2307 / 1940562$

Mulholland, P. J., Wilson, G. V., and Jardine, P. M. (1990). Hydrogeochemical response of a forested watershed to storms: effects of preferential flow along shallow and deep pathways. Water Resour. Res. 26, 3021-3036. doi: 10.1029/WR026i012p03021

Munn, N. L., and Meyer, J. L. (1990). Habitat-specific solute retention in two small streams: an intersite comparison. Ecology 71, 2069-2082. doi: 10.2307/1938621

Neal, C., Reynolds, B., Neal, M., Hughes, S., Wickham, H., Hill, L., et al. (2003). Soluble reactive phosphorus levels in rainfall, cloud water, throughfall, stemflow, soil waters, stream waters and groundwaters for the upper river severn area, plynlimon, mid wales. Sci. Total Environ. 314, 99-120. doi: 10.1016/S0048-9697(03)00099-8

Newman, E. I. (1995). Phosphorus inputs to terrestrial ecosystems. J. Ecol. 83, 713-726. doi: $10.2307 / 2261638$

Nihlgård, B. (1970). Precipitation, its chemical composition and effect on soil water in a beech and a spruce forest in south Sweden. Oikos 21, 208-217. doi: $10.2307 / 3543676$

Persson, G., and Broberg, O. (1985). Nutrient concentrations in the acidified lake gårdsjön: the role of transport and retention of phosphorus, nitrogen and DOC in watershed and lake. Ecol. Bull. 37, 158-175.

Peterson, B. J., Wollheim, W. M., Mulholland, P. J., Webster, J. R., Meyer, J. L., Tank, J. L., et al. (2001). Control of nitrogen export from watersheds by headwater streams. Science 292, 86-90. doi: 10.1126/science. 1056874

Prietzel, J., Klysubun, W., and Werner, F. (2016). Speciation of phosphorus in temperate zone forest soils as assessed by combined wet-chemical fractionation and XANES spectroscopy. J. Plant Nutr. Soil Sci. 179, 168-185. doi: $10.1002 /$ jpln.201500472

Qualls, R. G., and Haines, B. L. (1991). Geochemistry of dissolved organic nutrients in water percolating through a forest ecosystem. Soil Sci. Soc. Am. J. 55, 1112-1123. doi: 10.2136/sssaj1991.03615995005500040036x

Qualls, R. G., Haines, B. L., Swank, W. T., and Tyler, S. W. (2002). Retention of soluble organic nutrients by a forested ecosystem. Biogeochemistry 61, 135-171. doi: 10.1023/A:1020239112586

Raubuch, M., and Joergensen, R. G. (2002). C and net N mineralisation in a coniferous forest soil: the contribution of the temporal variability of microbial biomass C and N. Soil Biol. Biochem. 34, 841-849. doi: 10.1016/S0038-0717(02)00016-0 
Reckhow, K. H., Beaulac, M. N., and Simpson, J. T. (1980). Modeling Phosphorus Loading and Lake Response Under Uncertainty: A Manual and Compilation of Export Coefficients. Washington, DC: EPA publication

Rennenberg, H., and Schraml, C. (2000). Sensitivität von ökotypen der buche (Fagus sylvatica L.) gegenüber trockenstressforstwiss. Cent.bl. 119, 51-61. doi: $10.1007 / \mathrm{BF} 02769126$

Rier, S. T., and Stevenson, R. J. (2002). Effects of light, dissolved organic carbon, and inorganic nutrients $[2 \mathrm{pt}]$ on the relationship between algae and heterotrophic bacteria in stream periphyton. Hydrobiologia 489, 179-184. doi: 10.1023/A:1023284821485

Roberts, B. J., Mulholland, P. J., and Hill, W. R. (2007). Multiple scales of temporal variability in ecosystem metabolism rates: results from 2 years of continuous monitoring in a forested headwater stream. Ecosystems 10, 588-606.

Rodin, L. E., Bazilevich, N. I., Fogg, G. E., Technica, S., and Rodin, L. B. (ed) (1967). Production and Mineral Cycling in Terrestrial Vegetation. Edinburgh: Oliver \& Boyd Edinburgh.

Rosemond, A. D. (1994). Multiple factors limit seasonal variation in periphyton in a forest stream. J. N. Am. Benthol. Soc. 13, 333-334. doi: 10.2307/1467363

Runyan, C. W., Lawrence, D., Vandecar, K. L., and D'odorico, P. (2013). Experimental evidence for limited leaching of phosphorus from canopy leaves in a tropical dry forest. Ecohydrology 6, 806-817. doi: 10.1002/eco.1303

Saa, A., Trasar-Cepeda, M. C., Gil-Sotres, F., and Carballas, T. (1993). Changes in soil phosphorus and acid phosphatase activity immediately following forest fires. Soil Biol. Biochem. 25, 1223-1230. doi: 10.1016/0038-0717(93) 90218-Z

Schroth, G., Elias, M. E. A., Uguen, K., Seixas, R., and Zech, W. (2001). Nutrient fluxes in rainfall, throughfall and stemflow in tree-based land use systems and spontaneous tree vegetation of central Amazonia. Agric. Ecosyst. Environ. 87, 37-49. doi: 10.1016/S0167-8809(00)00294-2

Schuessler, J. A., Kämpf, H., Koch, U., and Alawi, M. (2016). Earthquake impact on iron isotope signatures recorded in mineral spring water. J. Geophys. Res. Solid Earth 121, 8548-8568. doi: 10.1002/2016JB013408

Schuessler, J. A., Von Blanckenburg, F., Bouchez, J., Uhlig, D., and Hewawasam, T. (2018). Nutrient cycling in a tropical montane rainforest under a supply-limited weathering regime traced by elemental mass balances and $\mathrm{Mg}$ stable isotopes. Chem. Geol. 497, 74-87. doi: 10.1016/j.chemgeo.2018.08.024

Schwärzel, K., Ebermann, S., and Schalling, N. (2012). Evidence of doublefunneling effect of beech trees by visualization of flow pathways using dye tracer. J. Hydrol. 470, 184-192. doi: 10.1016/j.jhydrol.2012.08.048

Sedell, J. R., Triska, F. J., and Triska, N. S. (1975). The processing of conifer and hardwood leaves in two coniferous forest streams: I. weight loss and associated invertebrates. Verh. Internat. Verein. Limnol. 19, 1617-1627. doi: 10.1080/03680770.1974.11896227

Snajdr, J., Cajthaml, T., Valášková, V., Merhautová, V., Petránková, M., Spetz, P., et al. (2011). Transformation of quercus petraea litter: successive changes in litter chemistry are reflected in differential enzyme activity and changes in the microbial community composition. FEMS Microbiol. Ecol. 75:291-303. doi: 10.1111/j.1574-6941.2010.00999.x

Sohrt, J., Lang, F., and Weiler, M. (2017). Quantifying components of the phosphorus cycle in temperate forests. Wiley Interdiscip. Rev. Water 4:e1243. doi: $10.1002 /$ wat 2.1243

Sparling, G. P., Hart, P. B. S., August, J. A., and Leslie, D. M. (1994). A comparison of soil and microbial carbon, nitrogen, and phosphorus contents, and macroaggregate stability of a soil under native forest and after clearance for pastures and plantation forest. Biol. Fertil. Soils 17, 91-100. doi: 10.1007/BF00337739

Spohn, M., and Widdig, M. (2017). Turnover of carbon and phosphorus in the microbial biomass depending on phosphorus availability. Soil Biol. Biochem. 113, 53-59. doi: 10.1016/j.soilbio.2017.05.017

Staelens, J., De Schrijver, A., and Verheyen, K. (2007). Seasonal variation in throughfall and stemflow chemistry beneath a European beech (Fagus sylvatica) tree in relation to canopy phenology. Can. J. For. Res. 37, 1359-1372. doi: 10.1139/X07-003

Stahr, S., Graf-Rosenfellner, M., Klysubun, W., Mikutta, R., Prietzel, J., and Lang, F. (2017). Phosphorus speciation and C: N: P stoichiometry of functional organic matter fractions in temperate forest soils. Plant Soil 427, 53-69. doi: 10.1007/s11104-017-3394-7

Stelzer, R. S., Heffernan, J., and Likens, G. E. (2003). The influence of dissolved nutrients and particulate organic matter quality on microbial respiration and biomass in a forest stream. Freshwater Biol. 48, 1925-1937. doi: 10.1046/j.1365-2427.2003.01141.x

Stevens, P., Hornung, M., and Hughes, S. (1989). Solute concentrations, fluxes and major nutrient cycles in a mature Sitka-spruce plantation in Beddgelert Forest, North Wales, For. Ecol. Manag. 27:1-20. doi: 10.1016/0378-1127(89)90078-9

Talkner, U., Meiwes, K. J., Potočić, N., Seletković, I., Cools, N., De Vos, B., et al. (2015). Phosphorus nutrition of beech (Fagus sylvatica L.) is decreasing in Europe. Ann. For. Sci. 72, 919-928. doi: 10.1007/s13595-015-0459-8

Thimonier, A., Schmitt, M., Waldner, P., and Schleppi, P. (2008). Seasonality of the $\mathrm{Na} / \mathrm{Cl}$ ratio in precipitation and implications of canopy leaching in validating chemical analyses of throughfall samples. Atmos. Environ. 40, 9106-9117. doi: 10.1016/j.atmosenv.2008.09.007

Timmons, D., Verry, E., Burwell, R., and Holt, R. (1977). Nutrient transport in surface runoff and interflow from an aspen-birch forest. J. Environ. Qual. 6, 188-192. doi: 10.2134/jeq1977.00472425000600020018x

Tipping, E., Benham, S., Boyle, J., Crow, P., Davies, J., Fischer, U., et al. (2014). Atmospheric deposition of phosphorus to land and freshwater. Environ. Sci. Process Impacts 16, 1608-1617. doi: 10.1039/C3EM00641G

Triska, F. J., Sedell, J. R., and Buckley, B. (1975). The processing of conifer and hardwood leaves in two coniferous forest streams: II. biochemical and nutrient changes. Verh. Internat. Verein. Limnol. 16, 1628-1639. doi: 10.1080/03680770.1974.11896228

Tukey Jr, H. (1966). Leaching of metabolites from above-ground plant parts and its implications. Bull. Torrey Bot. Club 93, 385-401. doi: 10.2307/2483411

Tukey Jr, H.B. (1970). The leaching of substances from plants. Annu. Rev. Plant Physiol. Plant Mol. Biol. 21, 305-324. doi: 10.1146/annurev.pp.21.060170.001513

Turner, J. (1981). Nutrient cycling in an age sequence of western Washington Douglas-fir stands. Ann. Bot. 48, 159-170. doi: 10.1093/oxfordjournals.aob.a086109

Uhlenbrook, S., Holocher, J., Leibundgut, C., and Seibert, J. (1998). "Hydrology, water resources and ecology in headwaters," in Using a Conceptual RainfallRunoff Model on Different Scales by Comparing a Headwater With Larger Basins, eds U. Tappeiner, N. E. Peters, R. G. Craig, and K. Kovar (Wallingford: IAHS), 297-305.

Uhlig, D., Schuessler, J. A., Bouchez, J., Dixon, J. L., and von Blackenburg, F. (2017). Quantifying nutrient uptake as driver of rock weathering in forest ecosystems by magnesium stable isotopes. Biogeosciences 14, 3111-3128. doi: 10.5194/bg-14-3111-2017

Uhlig, D., and von Blanckenburg, F. (2019b). Geochemical and isotope data on rock weathering, and nutrient balances during fast forest floor turnover in montane, temperate forest ecosystems. GFZ Data Services. doi: 10.5880/GFZ.3.3.2019.004

Uhlig, D., and von Blanckenburg, F. V. (2019a). How slow rock weathering balances nutrient loss during fast forest floor turnover in montane, temperate forest ecosystems. Front. Earth Sci. 7, 1-28. doi: 10.3389/feart.2019. 00159

Ulrich, B. (1983). "Interaction of forest canopies with atmospheric constituents: $\mathrm{SO}_{2}$, alkali and earth alkali cations and chloride," in Effects of Accumulation of Air Pollutants in Forest Ecosystems, eds B. Ulrich and J. Pankrath (Berlin: Umweltbundesamt), 33-45.

Verheyen, D., Van Gaelen, N., Ronchi, B., Batelaan, O., Struyf, E., Govers, G., et al. (2015). Dissolved phosphorus transport from soil to surface water in catchments with different land use, Ambio 44, 228-240. doi: 10.1007/s13280-014-0617-5

Vitousek, P. M., Porder, S., Houlton, B. Z., and Chadwick, O. A. (2010). Terrestrial phosphorus 968 limitation: mechanisms, implications, and nitrogen-phosphorus interactions. Ecol. Appl. 20, 5-15.

Voigt, G. K. (1960). Alteration of the composition of rainwater by trees. Am. Midl. Nat. 63, 321-326. doi: 10.2307/2422795

von Blanckenburg, F., Wittmann, H., and Schuessler, J. A. (2016). HELGES: Helmholtz Laboratory for the geochemistry of the earth surface. J. Large Scale Res. Facil. 2, 1-5. doi: 10.17815/jlsrf-2-141

Walker, T. W., and Syers, J. K. (1976). The fate of phosphorus during pedogenesis. Geoderma 15, 1-19. doi: 10.1016/0016-7061(76)90066-5

Webster, J., Tank, J., Wallace, J., Meyer, J., Eggert, S., Ehrman, T., et al. (2001). Effects of litter exclusion and wood removal on phosphorus and nitrogen retention in a forest stream, Internationale Vereinigung fur 
Theoretische und Angewandte Limnologie. Verhandlungen 27, 1337-1340. doi: 10.1080/03680770.1998.11901453

Werner, F., de la Haye, T. R., Spielvogel, S., and Prietzel, J. (2017). Smallscale spatial distribution of phosphorus fractions in soils from silicate parent material with different degree of podzolization. Geoderma 302, 52-65. doi: 10.1016/j.geoderma.2017.04.026

Winkelmann, C., Schneider, J., Mewes, D., Schmidt, S. I., Worischka, S., Hellmann, C., et al. (2014). Top-down and bottom-up control of periphyton by benthivorous fish and light supply in two streams. Freshw Biol. 59, 803-818. doi: $10.1111 /$ fwb.12305

Zavišić, A., Nassal, P., Yang, N., Heuck, C., Spohn, M., Marhan, S., et al. (2016). Phosphorus availabilities in beech (Fagus sylvatica L.) forests impose habitat filtering on ectomycorrhizal communities and impact tree nutrition. Soil Biol. Biochem. 98, 127-137. doi: 10.1016/j.soilbio.2016. 04.006
Zelazny, M., and Siwek, J. P. (2012). Determinants of seasonal changes in streamwater chemistry in small catchments with different land use: case study from Poland's Carpathian foothills. Pol. J. Environ. Stud. 21, 791-804.

Conflict of Interest: The authors declare that the research was conducted in the absence of any commercial or financial relationships that could be construed as a potential conflict of interest.

Copyright (๑ 2019 Sohrt, Uhlig, Kaiser, von Blanckenburg, Siemens, Seeger, Frick, Krïger, Lang and Weiler. This is an open-access article distributed under the terms of the Creative Commons Attribution License (CC BY). The use, distribution or reproduction in other forums is permitted, provided the original author(s) and the copyright owner(s) are credited and that the original publication in this journal is cited, in accordance with accepted academic practice. No use, distribution or reproduction is permitted which does not comply with these terms. 